Figure 1 When my 'theories- in- use' remained tacit

\section{What is hidden}

What I believe - my implicitly held theories-in-use
What they see

What I do - the classroom practice that I am modelling which is open to observation

For my own integrity I planned to teach using interactive strategies, strongly believing in the value of social

constructivism in learning. I was putting my beliefs into practice

What they do

Reflect on what they have seen

Decide what this will mean in their practice

Imitate good practice

Figure 2 When I articulated my 'theories-in-use'

What is hidden

\begin{tabular}{c|c}
$\begin{array}{c}\text { What I believe - my implicitly } \\
\text { held theories-in-use }\end{array}$ & $\begin{array}{c}\text { What I do - the classroom practice } \\
\text { that I am modelling which is open to } \\
\text { observation }\end{array}$ \\
\end{tabular}

For my own integrity I planned to teach using interactive strategies, strongly believing in the value of social constructivism in learning.

Theory in use $=$ espoused theory
What they see

What they do

Reflect on what they have seen and
heard
Ask me further questions
Decide what this will mean in their
practice

Imitate good practice

Embed explicit theories into their practice

Be able to articulate what they are doing
My espoused theory 